International Journal of Literature Studies (IJLS)

ISSN: $2754-2610$

DOI: $10.32996 /$ ijts

Journal Homepage: www.al-kindipublisher.com/index.php/ijlss

\title{
The Unemployed Main Character in the Fiction of Kunut Hamsun and Najeeb Mahfouz: A Comparative Study in the Light of Sustainable Development
}

\author{
Abdel Kareem Qutb Shehata \\ Associate Professor, Department of English-Faculty of Languages and Translation, October 6 University, Egypt \\ $\square$ Corresponding Author: Abdel Kareem Qutb Shehata, E-mail: Abdelkareem.Qutb.Lan@o6u.edu.eg
}

\begin{abstract}
ARTICLE INFORMATION ABSTRACT
Received: 11 October 2021

Accepted: 25 October 2021

Published: 04 November 2021

DOI: $10.32996 /$ ijts.2021.1.1.8

\section{KEYWORDS}

Unemployed Character, Fiction, Kunut Hamsun, Najeeb Mahfouz, Comparative, Sustainable

Development

The Norwegian novelist Kunut Hamsun published his novel Hunger in 1921. The novel was translated into English by George Egerton. In this novel, Hamsun introduces the character of Andereas Tangen, a journalist who has a good life but starts to lose his living, and his essays begin to be refused. He becomes unemployed and suffers poverty, hunger, and homelessness for some time. By the end of the novel, he finds a job on a ship that is sailing from his town Christiania to fetch coal. During the 1930s the Egyptian novelist and short story writer Nageeb Mahfouz wrote his collection of short stories (Hams Eel- Gnoon) The Whisper of Madness. Among this collection, he published his short story (Al- Goo) The Hunger. In this short story, the main character, Ibrahim Hanafy has been working in a factory until he cuts his arm in an accident and loses his job. He becomes unemployed and he, with his family, suffers hunger and many social and psychological difficulties. He hates his life, tries to commit suicide but is saved coincidently by the son of the factory's owner. The man promises Ibrahim to find him a job. This paper aims to show that the unemployed main character in Hamsun's and Mahfouz's works is unable either to love a partner or to have a friend and if he is married, he is unable to keep his marriage relation. Another aim of the paper is to shed light on the negative relations of the unemployed character on one side with his god and with the government of his country on the other side. The third aim of the paper is to emphasize that unemployment, in Hamsun's and Mahfouz's works, leads the once good character to try to commit suicide. Thus the paper comes into three parts: the first part deals with Tangen's failure to have a love relation or enjoy a friendship. This part also tackles Hanafy's disability to protect his love for his wife. The second part introduces Tangen's criticism of his god and of the government in his country. In the third part, the paper discusses the once good characters, becoming unemployed, thinking of death as a solution, and may try to commit suicide. The paper depends on the theory of needs' priority and the method of social and psychological analysis in tackling its topic.
\end{abstract}

\section{Introduction}

The Norwegian novelist, Kunut Hamsun published his novel Hunger in 1921. The novel was translated into English by George Egerton. In this novel, Hamsun introduces the character of Andereas Tangen, a journalist, who has a good life but starts to lose his living and his essays begin to be refused. He becomes unemployed and suffers poverty, hunger, and homelessness for some time. By the end of the novel, he finds a job on a ship that is sailing from his town Christiania to fetch coal.

During the 1930s the Egyptian novelist and short story writer, Nageeb Mahfouz wrote his collection of short stories (Hams EelGnoon) The Whisper of Madness. Among this collection, he published his short story (Al-Goo) The Hunger. In this short story, the main character, Ibrahim Hanafy has been working in a factory until he cuts his arm in an accident and loses his job. He becomes

Copyright: (C) 2021 the Author(s). This article is an open access article distributed under the terms and conditions of the Creative Commons Attribution (CC-BY) 4.0 license (https://creativecommons.org/licenses/by/4.0/). Published by Al-Kindi Centre for Research and Development, London, United Kingdom. 
unemployed and he, with his family, suffers hunger and many social and psychological difficulties. He hates his life, tries to commit suicide but is saved coincidently by the son of the factory's owner. The man promises Ibrahim to find him a job.

The unemployed person, being poor, hunger, homeless, and of unsuitable clothes, is unable to have a normal social life. He loses the desire to have a friend, to live a love story, or to establish a family. Regarding human nature, this happens according to the theory of needs' priority, "Maslow's need hierarchy organizes human needs from more basic to more social..., when hunger is satisfied, it becomes unimportant to individual, and is instead replaced by higher-order needs"( Pettijohn, 2012,p. 1-2). So, as long as the individual suffers hunger, he is unable to have a friend or a love relation.

Man earns his living mainly to meet his and his family's need for food, the basic element behind man's motivation in life. Pettijohn explains, "Alderfer's ... theory of motivation... sexual interaction, dating, and affiliation with friends would be classified as relatedness needs... when hunger is satisfied, the social needs of sexual activity, dating, and friendship affiliation will increase in motivation" (2012, p.2). When food is available and enough to meet man's hunger, his sexual desire and his social needs to become a member of a family or a partner of a friendship relation become increasingly motivated.

Facing unemployment and decreasing the number of the unemployed are the main goals of the United Nations project of sustainable development. Everyman has the right to have a job and to earn his and his family's living. The "environmental justice encompasses much more- transport and access, air quality (and less) pollution, poverty, poor housing, unemployment" (Blewitt, 2008. P. 87). The unemployed people suffer a type of severe aggression from their societies and from the world. It is a matter of justice to find a job for every person where- ever he or she lives.

Literature, through works like Hamsun's novel and Mahfouz's short story, plays its role in achieving sustainable development aims. The two literary works help by introducing the unemployed characters to show the bad effects of unemployment on their social activities and consequently evoke the societies to solve the problem and find jobs for their unemployed individuals. Mahfouz had written a large number of stories during the 1930s (many of which are now to be found in the collection, The Whisper of madness. "These stories show some of Mahfouz's concerns with contemporary issues" (Allen, 1982, p. 56). And "his works reflect..., common sense, and sympathy for the confused and oppressed" (Moosa, 1997, p. 372). In the meantime, modern novel in Europe contributes to anticipating and showing man's problems to the European societies and to the world to solve.

This paper aims to show that the unemployed main character in Hamsun's and Mahfouz's works is unable either to love a partner or to have a friend and if he is married, he is unable to keep his marriage relation. Another aim of the paper is to shed light on the negative relations of the unemployed character on one side with his god and with the government of his country on the other side. The third aim of the paper is to emphasize that unemployment, in Hamsun's and Mahfouz's works, leads the once good character to try to commit suicide. Thus the paper comes into three parts: the first part deals with Tangen's failure to have a love relation, or enjoy a friendship. This part also tackles Hanafy's disability to protect his love for his wife. The second part introduces Tangen's criticism of his god and of the government in his country. In the third part, the paper discusses the once good characters, becoming unemployed, thinking of death as a solution, and may try to commit suicide. The paper depends on the theory of needs' priority and the method of social and psychological analysis in tackling its topic.

$-1-$

Employment offers the individuals what is usually called social protection. The employed person confidently lives and moves between his factory and his house. In "the everyday life of people in capitalist societies, employment and welfare lie at the center of ... social protection. It represents the totality of public policies and institutions designed to shield individuals from social harm" (Ramia, 2020, p. 3). Thus, having a job and a salary in a capitalist society means safety and security from social harms such as loneliness, poverty, and dangers.

The employed individuals in such societies are enthusiastic about establishing social relations and about joining general unions. M. Frege explains, "with regard to the reasons for 'joining' the western unions in 1990, most academics argue that people demonstrated a highly instrumental decision-making approach"(1999, p. 98). The employed individual feels confident and safe in his society. He is not frightened to be close to the other members of his society. On the contrary, he may feel proud of being a positive partner in personal and social relations.

On the other hand, the insecurity of employment threats the peace of man's life in any type of societies "Job and employment insecurity corporate restricting continuous change and workplace level lead to a general feeling of insecurity, which is aggravated by the fact that people have hardly any voice in the processes of change" (Flecker, 2007, p. 242). Any change in the job processes, even in the place of the job, which happens against the will of the individual, damages the peace of his life. Then, what may happen to the individual if he completely loses his job and becomes unemployed!? 
The two characters, Tangen in Hamsun's Hunger and Hanafy in Mahfouz's the Hunger, being unemployed, are unable to establish or even keep normal personal and social relations. Tangen fails to be a friend or a partner in a love relationship with the street wench and he does not succeed in his love relation with the Ylajali. Hanafy, in Mahfouz's the Hunger, under the stress of unemployment, poverty, and hunger, easily doubts the loyalty of his wife and decides to leave her.

Tangen does not have the desire or the look to attract the street wench. She "came out into the street 'How is the world treating you, old fellow? Eh, what, are you ill? Nay, the Lord preserve us, what a face?' And she drew away frightened" (Hamsun, 2010, p. 87). The young man is hungry, sick, and looks very old and weak. "Alderfer suggested that when existence needs are satisfied, the relatedness needs are more likely to be desired" (Pettijohn., 2012, p. 2). Tangen's existence needs for food are not sufficiently met so his needs for sexual activities do not express themselves in his look and behaviors. He does not care about how he is seen by the street wench who runs away. She is frightened by his miserable state.

However, Tangen's failure in his once-promising relation with Ylajali is evidence of his social abnormality throughout the time of the relation. "The unemployed person loses self-esteem, .... and a sense of connection to society" (Petersen, 1994, p. 307). His relation with the girl well starts when (he says): "I brushed one of them accidentally on the arm... But she blushes, and becomes suddenly surprisingly lovely... Her high, full bosom heaves violently several times" (Hamsun, 1994, p. 16-17). Simply, the girl and Tangen admire each other.

In such situations, the young man is expected to behave friendly and gently but the absence of self-esteem and the abnormal connection with society lead Tangen to behave in a strange way. He explains, "I feel seized with an odd, and gaze into her eyes, and hit, on the spur of the moment, on a name which I have never heard before... a name with a gliding, nervous sound... Ylajali" (1994, p.17). Instead of gently expressing his admiration, he intentionally starts to frighten the girl. He does not introduce himself to the girl and asks about her real name. He prefers to give her a strange name.

Tangen's psychological problems because of his being unemployed and hunger spoil his second meeting with the girl and destroy the relationship completely at the end of the third meeting, "psychosomatic problems, powerlessness and depression are considerably greater among those exposed to a higher degree of financial hardship and more shaming experiences" (Kieselbach, 2000 , p. 38). His poverty brings his depression and turns their second meeting into a nightmare.

The girl comes to their date on time to find Tangen not ready to enjoy the meeting. He describes himself, "here I stood before a young lady, dirty, ragged, torn, disfigured by hunger, unwashed, and only half-clad; it was enough to make one sink into the earth" ( Hamsun, 2010, p. 117). He is so depressed that he wishes to hide from the eyes of his girlfriend. Those thoughts are enough to turn their second meeting into a difficult situation for both of them.

The unemployed character's lack of self-esteem and sense of social connection besides his depression is behind ending his love relation. In his third and last meeting with Ylajali, Tangen confesses, "I talked a long time over these sears my soul had. But the longer I talked, the more troubled she grew" (2010, p.148). Influenced by the terrible difficulties that Tangen suffers, the girl gets frightened. Although he can see the girl is getting badly affected, he continues until she feels that she must end this relationship and let him leave her home. So, Tangen describes the end of their relation, "she wound her arms around my neck; she had tears in her eyes,.. it was quite certain she was making a sacrifice as a means of putting an end to all this" (2010, p.149). In spite of their love, the girl is unable to stand listening more to the desperate young man, she prefers to end her love relation and search for a more hopeful one.

Tangen, then, as an unemployed young man, could not live a love relation. Both the street wench and the girl Ylajali, who falls in love with him, can not bear his depression. Because of his unemployment, he loses his self-esteem and the natural human social connection with others. In his case, his need for food is not sufficiently met, so the need for attraction to the other sex is not enough motivated. His sad look and unsuitable clothes beside the influences of long-suffering, frighten the two girls. So the street wench runs from him and Ylajali exerts a terrible effort to get him out of her life.

Similarly, Hanafy in Mahfouz's short story doubts his wife's love for him. He thinks that she does not belong to him anymore. "Psychologically, as well as economically, unemployment is a condition of forced dependence, which makes the individual deeply vulnerable to others" (Feather, 1990, p. 49). Because of poverty, the family accepts to take bread from the baker, Sulieman, the man, who wanted to marry Hanafy's wife in the past. The appearance of Sulieman in their life destroys Hanafy's relation with his wife. Hanafy asks his son about the bread, "Who brought the bread" The boy answers "uncle Sulieman, the baker"... " Did the man call your mother to the baker's or he came here himself?" (Mahfouz, 2006, p. 145- 146). Here, the unemployed character Hanafy, because of poverty and hunger is, unwillingly exposed and is forced to accept the presence of that man in their life. It is so clear from Hanafy's question that he becomes away from his wife. He starts to lose his trust in his love relationship with his wife. He leaves the place silently. 
The unemployed Tangen does not have love relations, and he is unable to have friends too. Having a job encourages man to have many acquaintances, "Work makes you feel good about who you are and what you can do, then desire to connect with others and to be part of larger communities of people is stimulated... with time, work provides its own safety net for people" (Marrone, 2012,p. 6). So the job gives the man self-confidence and a desire to connect with society and be a member of a great community. Having a job makes the man feel safe and consequently, he seeks to connect with other people without fearing their relations. On the contrary, Tangen does not have a job so he does not feel safe and has no self-confidence. He speaks to himself, "had I not a friendan acquaintance whom to could apply to? I ransack my memory to find... and fail to find him" (Hamsun, 2010, p. 71). So he does not have friends too. Alone he faces the terrible results of unemployment.

Hamsun's Tangen, being a writer, through imagination can enjoy his love relation with Ylajali. More than once, his imagination takes him to his princess Ylajali, "dark monsters out there will draw me.... And they will bear me far across the sea... to princess Ylajali's palace... I clasp her hand in mine; I feel the wild witchery of enchantment shiver through my blood" (2010, p.59). The hungry Tangen could have the joys of love only in his daydreams, however, through imaginative monsters and on the other side of the sea.

Another time Tangen also through his imagination meets Ylajali and eats beef. Ylajali calls him, "Come in! yes, only come right in! As you see everything is of ruby ... Ylajali, Ylajali ... Ah, how passionately she breathes. Kiss me... your arms are like pale amber, your mouth blushes... Waiter I asked for a plate of beef!" (2010, p.73). Only in his imagination, the unemployed have the confidence to answer his beloved girl's invitation and enter her rich world to enjoy sex and food.

$-2-$

Most of the time Tangen thinks of his god as responsible for the difficulties of his life. Hamsun could draw the character of the unemployed who is suffering tyranny and injustice of his society. Also Mahfouz "could not be a part of Arab society and yet not concern himself with ... tyranny, injustice, poverty, deprivation (and) ... repression" (Allen, 1982, p. 63). Being alone and disconnected from their societies the characters in the two works are expected to search for other greater powers to meet their need for food and to carry the responsibility of the world's tyranny and injustice. "Was the hand of Lord turned against me? ... why not select just as well Bookseller Pascha, or Hennchen the steam agent? ... I found the most weighty argument against the Creator's arbitrariness in letting me pay for all the others' sins" (Hamsun, 2010, p. 22). Tangen blames his god for selecting him and not another one to suffer poverty and hunger. He also does not accept from his god to make him another Jesus to be crucified and to suffer for the sins of the others.

Later on, he sees that God does not care about his destruction. He thinks of his god as a careless one "And up in Heaven God Almighty sat and kept a watchful eye on me, and took heed that my destruction proceeded in accordance with all the rules" (2010, p.50). Although he clearly sees what happens to His worshiper, the powerful god who is able to change his fate does not do anything for Tangen. His god watched his destruction which is being executed according to the rules of a system that is made by that god.

In the other two situations, Tangen decides to be more positive in his relation with his god. Firstly, he fails to sell the shaving tickets and the tie. He describes the situation when he is obliged to raise his voice in his one-sided dialogue with god. He is also physically excited, walking, weeping, and crying, "I became so touched at my own words, they sounded so pathetic in the twilight that I feel a - weeping... I walked and cried as I walked, ... ' Lord God, I feel so wretched! Lord God, I feel so wretched!' "(2010, p. 54). Tangen complains about his poverty and wretchedness to his god. He cries and repeats twice his complaint. When this development fails to move his god to help him, he tries another way with his god.

Secondly, Tangen states that he hates his god and does not believe in him anymore. In his dialogue with his god, he shouts to Him: " I tell you, ... you don't' exist, but that, if you did, I would curse you so that your Heaven would quiver .. I have offered you my service and you've pulsed me" (2010, p.132). Tangen blames his god for not doing his duty, of not being grateful. He states that he is no longer a Christian. Tangen suffers injustice and tyranny of the world. He asks his god to help him but nothing happens and he continues to suffer poverty and hunger.

Different from Tangen, Hanafy, the unemployed character in Mahfouz's short story does not blame his god. He accepts the loss of his job in the factory as his fate. Instead, he sees that the owner of the factory is responsible for his difficulties. He described how the rich man reacts to his asking for help, "I went to the owner of the factory, broken-hearted, in complete despair, he sorrowfully received me and stated that I carelessly cut my arm. I told him that it is an unpreventable fate. He nodded in sorrow and gave me little money" (Mahfouz, 2006, p. 144). In Hanafy's point of view, the owner of the factory is responsible for the poverty and hunger that he and his family suffer.

Government as another power in the modern world, which a man can ask for help, is not thought of by Hanafy in Mahfouz's short story. However, the policeman or the constable as a symbol of the government is seen several times in Hamsun's novel. In most 
situations, the policeman either has a negative effect on Tangen or just watches him. Tangen complaints: " whilst I was standing laboring at this, the constable came and planting himself a little distance away from me spoilt my whole mood" (Hamsun, 2010,p. 102). Here the homeless writer is in the street trying an essay but the interfering policeman disturbs his thinking and gets him out of his good mood of writing. So, the policeman has a negative influence on Tangen's try to write, and he also has negatively affected Tangen's love relation.

The policeman spoils Tangen's happy time during his third and last meeting with Ylajali. Tangen describes the situation. "We had begun to walk on involuntarily. A policeman is standing at the corner, looking at us" (Hamsun, 2010, p. 138). The two lovers start to wander unwillingly in the street. They just enjoy being together and do not bother themselves with anything around them. They do not even choose their way. However, Tangen discovers that they are being watched by the policeman. This behavior hurts the privacy of Tangen and negatively influences his time with Ylajali.

In Hamsun's novel, the government does not solve the problems of the unemployed writer. They are satisfied by the job of watching him in his private situations. Near the end of his suffering, Tangen finds himself, during a fit of anger, cutting the papers of his intended play, and "a policeman is standing a few steps away, watching me" (Hamsun, 2010, p. 178). So, the government, represented by a policeman, is always there very near to Tangen, in many of the stages of his suffering. However, they do not try to help, they only watch him.

Only once, the government is mentioned as a source of help for Tangen. It is very cold and he does not find a place to spend the night, the policeman advises Tangen, "well then, you must go to the guard-house and report yourself as homeless!" (Hamsun, 2010, p. 64). Tangen spends the night in the guardhouse and in the morning is allowed for breakfast but because of his pride, he leaves still hungry. The police are part of the government that could help Tangen at that night but they do not solve any of his problems. The next day he returns to the street homeless and hungry.

Thus the two unemployed characters Tangen and Hanafy do not find solutions for their problems of poverty and hunger through the owner of the factory, gods, or governments. In spite of doing his services Tangen's god only watched his suffering hunger and cold. The government is seen only through the policemen and the constables who do nothing but watch Tangen even on his dates with Ylajali. Hanafy does not think that God is responsible for his problems and he does not say anything about the government. He thinks that his fate and the owner of the factory are responsible for his and his family's hunger. So death comes to be Tangen's decision in several situations and Hanafy's final decision.

-3-

The two characters, Tangen in Hamsun's novel and Hanafy in Mahfouz's short story do not start as unemployed characters. Tangen talks to himself that for a co\nsiderable time in his life, he was able to earn a good living. Hanafy also had a job and could have a salary. So, becoming unemployed they are severely influenced, Tangen fails to have help from his god and the owner of the factory gives Hanafy just very little money. Consequently, the unemployed characters see death as a way to end their suffering until a job or a promise of a job comes to save each of them.

Tangen remembers the time when things were going well with him. Unemployment and poverty terribly influence his skills and his articles become no longer preferable by the editor. Similarly, Hanafy recalls: "In the past, I had been able to have a wife and to spend money... I had been a worker in a factory... The daily pay reached six piasters" (Mahfouz, 2006, p. 143- 144). Tangen and Hanafy then used to work, to earn money, and to live easily so their unexpected difficulties terribly affected them,

To live under a high degree of economic stress means living under a considerable threat that there will not be enough funds for the most basic necessities...

The other important emotions are shame and humiliation which arise partly as a consequence of how a person believes she/ he is regarded by others. (Kieselbach, 2000, p. 41)

These feelings of shame and humiliation are expressed when the two characters speak of their past life and their lost pride and respect.

Tangen's feeling of pride increases his problems, makes them more difficult and many times prevents him from finding solutions. Because of his pride, he could not go back to his rent room; "My pride forbade my returning to my lodging... besides, it could never really occur to me to go back on my word; I rejected this thought with great scorn" (Hamsun, 2010, p. 3). It is a very cold night and he may have the chance to go back to his room and to spend the night but only because of his pride and not to change a decision he has already made, he contempts the idea.

Tangen's pride also forces him to refuse another idea to end his suffering by going to his uncle. He proudly thinks, "it suddenly entered my head that I might just as well turn rogue at once and go to my "Uncle's"...then turned back...delighted I became, that 
I had conquered this strong temptation" (2010, p.47). Refusing the temptation to resort to his uncle's house delights him. He prefers rather keep suffering than to be helped by his uncle.

Similarly, Hanafy speaks of himself in the past, he tells the gentleman: "and I had been respectful and reliable and I ensured good life for my wife and children. I had been more patient than the owner of the big factories because I used to be satisfied and contented" (Mahfouz, 2005, p. 144). When he had a job, he was able to spend money and offer a good living for his family. He had been also more patient than the rich people. So he enjoyed self-respect and pride.

Hanafy's pride costs him so much. His pride prevents him from asking for help from others. He shows the results: "Allah knows, I was of great pride, and oppressing this noble feeling costs me much pain and shame. Life difficulties got stronger, I sold the furniture, our clothes were torn, and my children became naked. Hunger perished all the members of the family" (2006, p.145). Because of poverty and hunger, Hanafy sold the furniture of the family. He could not buy new clothes for himself, his wife, and his children. The family lost the light of the life grace.

Pride and self-respect increase the suffering of the unemployed characters Tangen and Hanafy. The unemployed character is not only disabled to have a friend or a normal love relation, he may hate his life also and may think of ending this life. Feather refers to, "The particularly negative effects that unemployment has on the affective- well- being of middle-aged men... their loss of income following job loss may also be dramatic, especially if they were on high salaries or received extra payments"( p.1990, 77). The reaction of losing the income could be terribly exaggerated. It ranges from feeling loneliness to the character's thinking of committing suicide.

In such cases, the effects of unemployment influence the unemployed and the people around him, "alienation and increased deviant and antisocial behavior are assumed to be the effects of unemployment... unemployed young person is at increased risk for displaying suicidal behavior" ( Kiseblach,2000, p. 21). The unemployed characters Tangen and Hanafy feel loneliness and alienation. Tangen cannot continue a normal love relation and is unable to keep a friend. Hanafy loses trust in his wife. The two characters also think of death as the end of their suffering.

At the very beginning of his suffering, Tangen thinks of death to end his difficult life. He justifies," The frequent repulses, half promises and curt noes, the cherished deluded hopes, and fresh endeavors that always resulted in nothing had done my courage to death" (Hamsun 2010, p. 10). Tangen here mentions his reasons to be more courageous to think of committing suicide; he was frequently repulsed and disappointed by the unfulfilled promises and the unreal hopes.

Again near the end of his suffering time, Tangen feels that he is nearer to death than to life. He describes his state;" I had a feeling that there was not much life left in me- that I was really singing my last verse... I would have willing laid myself down flat in the street to die" (2010, p. 133). He is physically and spiritually exhausted. He feels that his lifetime finished and it is time to die.

The unemployed character in Mahfouz's short story, Hanafy is more decisive to commit suicide and is saved during his trial. The high-class gentleman, Mr. Mohamed Abdel Qawi notices

a man of bad shape and dirty clothes leaning over the short wall of the

bridge over the river Nile... firstly the gentleman does not pay any

attention, when he becomes nearer to the man, he saw him while was

jumping with a sudden move up to the top of the wall as if to throw

himself into the Nile. Quickly. Mr. Mohamed rushed towards him

caught him and palled him back to save him. (Mahfouz,2006, p. 142)

It is Hanafys complete, clear, and decided attempt to commit suicide, to kill himself, drowned in the River Nile. When Hanafy is asked by Mohammed Abdel Qawi, "Did you really want to kill yourself? (Hanafy answered) ... I am hungry" (2006, p.143). Poverty and hunger, the outcome of the unemployment are the motivation of Hanafy's trying to throw himself into the Nile.

The once respectful journalist Tangen and the once good and patient worker, Hanafy hate their lives and they prefer to die because of their severe difficulties of poverty and hunger. One thing can end the suffering of the unemployed character. It is the job. In Hamsun's novel, Tangen is lucky and he finds a job for himself. On the beach of the town, he starts to talk with the captain of a ship. He happily recalls the situation:

"Do you sail tonight, Captain?" 
"Yes, in a short time", answered the man. He spoke Swedish.

"Hem, I suppose you wouldn't happen to need a man?"...

"Well. No," he replied;" unless it chanced to be a young fellow."

"A young fellow! " I pulled myself together, took off my glasses

furtively and thrust them into my packet, stepped up the gangway,

and strode on deck. (Hamsun, 2010, p. 184)

Tangen regains his young shape and jumps to the ship to end his unemployment and his suffering.

In Mahfouz's short story Mohammed Abdel Qawi gives Hanafy another hope in life. He confirmly tells Hanafy; "You still have a hope in life I'll find you a job, a porter or a servant. Come forward and restore your mind..." (2006, p. 147). So, that confirmed promise of a job ended the suffering of the unemployed Hanafy and returned him back to being an employed, respectful man.

Thus, Tangen in Hunger had a source of living as an essay writer. For a long time, he felt self-respect. He becomes unemployed only for some time, during which he hates his life and thinks of death as a possible end to his suffering. Hanafy, in Mahfouz's short story, had a job in a factory and used to earn a salary enough to look after his family. The loss of his job brings him and his family a severe experience of hunger, homelessness, and frustration. He not only thinks of death as a solution but he also tries to commit suicide. Fortunately, Tangen finds a job, and Hanafy is promised a job at a suitable time to stop their suffering and bring them back to the shield of employment.

\section{Conclusion}

To conclude, the unemployed main characters in Kunut Hamsun's novel, Hunger and in Nageeb Mahfouz's short story, Al Goo (The hunger), suffer severe social and psychological difficulties because of being unemployed. Tangen is unable to have a friend or to establish a love relation and Hanafy cannot keep his love for his wife. Tangen fails to have the help of his god and the owner of the factory refuses to help Hanafy. Being unemployed, the two main characters are disconnected from their societies. Only in his imagination, the unemployed Tangen has the confidence to answer his beloved girl's invitation, enter her rich world.

Before being unemployed, the two characters had a normal social life, each in his society so the unemployment caused them several social problems. Tangen enjoyed good family and friendship relations. He had good self-esteem and was proud of himself. Hanafy had a good family and was able to spend money and offer them a respectful life. So, each of the two characters, Tangen and Hanafy, becomes severely disappointed and starts to think of death as a solution to his suffering, as in Tangen's case, or to try to commit suicide as in the case of Hanafy.

The two unemployed characters continue their suffering of poverty and hunger and their social disability until Tangen can find a job on a ship and Hanafy is promised a job. Thus the unemployed character in the two works is proved to suffer social disability until he has a job. Only with returning to work the suffering of the two characters is expected to stop.

The paper introduces the two literary works, Kunut Hamsun's novel Hunger (1921) and Nageeb Mahfouz short story (Al- Goo) The Hunger, as they do the role of literature in showing unemployment as a terrible problem for the individuals and societies in our world. The UN sustainable development goals include facing unemployment in the different societies as the main goal. This paper comes to discuss the two works and to explain the building up of the main characters, which may highlight the terrible results of unemployment. Consequently, the paper emphasizes the importance of the efforts of world organizations and governments to solve that problem.

\section{References}

[1] Allen, R. (1982). The Arabic Novel: An Historical and Critical Introduction. Syracuse University Press.

[2] Blewitt, J. (2008). Understanding Sustainable Development. Dunstan House.

[3] Feather, N. T. (1990). The Psychological Impact of Unemployment. Springer- Verlag.

[4] Flecker, J. (2007). Change in Working Life and the Appeal of the Extreme Right. Ashgate Publishing.

[5] Hamsun, K. (2010). Hunger. Trans. George Egerton. New York: Alfred A. Knopf. E Book\# 8387. 23/ 8/ 2010. 1/ 9/ 2020.

[6] Kieselbach, T. (2000). Youth Unemployment and Health: A Comparison of six European Countries. Springer Fachmedien Wiesbaden. Ursprunglich Erschienen Beileske+ Budrich.

[7] Mfrege, C. (1999). Social Partnership at Work: Workplace Relations in Post- unification Germany. Routledge.

[8] Mahfouz, N. (2006) "Al Goo (The Hunger)". Hams Al Gnoon (The Whisper of Madness). Dar Al Shrouk.

[9] Marrone, J \& Ed G. (2012) "If Work Makes People with Mental Illness Sick, What Do Unemployment, Poverty, and Social Isolation Cause?" Speaking Out psychiatric Rehabilitation Journal. 23,(2).187-193). Why-work-Marrone. 18/ 4/ 2012. 5/ 1/ 2021. 
[10] Moosa, M. (1997). The Origins of Modern Arabic Fiction. Lynne Rienner Publishers.

[11] Petersen, A. C. \& Jeylan T. M. (1994). Youth Unemployment and Society. Cambridge University Press.

[12] Pettijohn, T. (2012). "Hunger and Social Motivation: Hungry People are Less Interested in Social Activities than Satiated People". Current Psychology. 31:1-5. New Brunswick, N.J.

[13] Ramia, G. (2020). Governing Social Protection in the Long Term: Social Policy and Employment relations in Australia and New Zealand. Global Dynamics of Social Policy. 